\title{
Analysing Live Music in the UK: Findings One Year into a Three-Year Research Project
}

\author{
Simon Frith \\ simon.frith@ed.ac.uk

\section{University of Edinburgh}

\begin{abstract}
This is the first of four related articles in this journal presenting findings from an ongoing research project on the history of live music in the UK since 1950. This introductory article outlines the project's starting assumption-that popular music culture in this period was organised around the constantly changing relationship of the recorded music and live music sectors-and suggests that this is to challenge the conventional academic assumption that the post-war history of popular music can be written as the history of the record industry. To approach popular music history from the perspective of live musical promotion means a) rethinking periodisation; b) examining a very wide range of musical activities; c) paying attention to the regulatory and the promotional roles of the state; d) understanding the importance of locality and place; e) reconceiving the power structure of musical institutions.
\end{abstract}

Keywords: live music, promotion, the state.

In his excellent book, Making Easy Listening. Material Culture and Postwar American Recording (University of Minnesota Press 2006), Tim J. Anderson suggests that "the period from after World War II to the rise of rock music as the dominant genre of the day" has been underresearched. This was the time, he suggests, when "the recording, in effect, replaced sheet music as the dominant material unit of exchange and musical distribution", and the final effect of this transition was profound:

Indeed, no single history or historian could do justice to this change, for its impact was so widespread and so fundamental that the record would overtake the importance of live performance in terms of its industrial, aesthetic, and, eventually, cultural influence (Anderson, 2006, pp.xviii-xix). 
Anderson is right to argue that the postwar rise of recordings to musical dominance didn't just happen (and that the pre-rock era has not had sufficient attention in popular music studies) but his conclusion about the relative cultural importance of recording and live music is, I think, generally accepted. Who in popular music studies would disagree with this summary?

The basis of the prewar music industry was live performance of music by amateurs and professionals. Whether it involved the purchase of to-beperformed sheet music, ticket sales, or using musicians as attractions for the sponsored broadcasts, the live performance was the major method through which music was appreciated, danced to, consumed, listened to and anticipated. After the war, the music industry systematically altered itself around recordings, all of which are vital to our modern-day conception of how we conceive of popular music (Anderson, 2006, p.7).

On the other hand, I suspect that even Anderson might modify this assertion a little in the light of developments since he wrote-there are certainly elements of musical culture today that seem more akin to his pre-war than post-war situation. My point is that over the last fifty years popular music culture has been organised around the relationship of the recorded music and live music sectors and this relationship is constantly changing. This is the context for our research project. We wanted to look at the history of British popular music since 1950 from the perspective of the live music sector rather than assuming (as do most popular music histories) that the postwar history of popular music is, in effect, the history of the record industry.

What are the effects of this shift of perspective? To be schematic:

a) a clear sense that over the last 50-60 years we have had three popular music eras. I think of these as pre-rock (1950s-60s), rock (1970-80s) and post-rock (1990s-2000s), in each of which recorded and live music have a different sort of economic and cultural co-existence. This argument is developed in Brennan's corresponding article in this journal, but I should stress that live music history isn't a matter of a sector rising or falling. Live musical performance is a continuously necessary aspect of musical culture and one of the fascinations of the live music business is promoters' ability to adapt to ever-changing circumstances.

b) There are many kinds of live performance that can be classified according to a variety of criteria:--amateur/professional, public/private, primary/secondary-and which involve a variety of economic arrangements (commercial, charitable, state subsidised, corporately sponsored, etc.). To be interested in live performance in general (as we are) is therefore to have a much richer sense of British musical life than a focus on record production and distribution and, in particular, of the complexity of what it means to be a popular musician.

c) The (local and national) state has a much more significant role in live than recorded music. Its role is partly regulatory-live music is 'licensed' and the history of licensing regimes and their effects on musical venues, gatherings, etc is fascinating in itself (this point is developed in Cloonan's corresponding article 
in this journal). But the state's role is also promotional, investing in and subsidising certain sorts of musical activity and venue. This is not just a matter of arts or tourist policy, it also involves, for example, youth and multicultural policythink of the role of community centres and resources in the history of black British music.

d) Live music (as the work of Sara Cohen and her colleagues in Liverpool has shown) is particularly significant for understanding musical locality and place. ${ }^{1}$ Live music has to happen somewhere, and the changing places of music (where live events happen, the geography of audience) are a crucial strand of social history. And the place of live music is also a venue, whether a pub back room, a farmer's fields or a purpose built stadium. The changing spaces of musical performance contain their own technological, architectural and ideological accounts of what people have understood as a good sound, a good performance, a good listening experience, a good night out. Webster discusses this further in her corresponding article in this journal.

e) To look at the business of music from the promoter's perspective is to get a different sense of the musical power structure than that provided by the record industry (which has, interestingly, tended to treat promoters as the most shady and untrustworthy players in the musical game). Promoters have both a different immediate sense of the problem of juggling with many interests at once (artists, managers, agents, venues, regulators, record companies, audiences) and a different long term understanding of musical careers and audience needs-to look after an artist starting out is to benefit from their market value when they become big stars; to look after this audience for this show is to ensure they come back for the next one. The promotional business is a mess of contradictions-a contract based business without contracts, an exploitative business based on face-to-face goodwill, a highly regulated business which often seems close to chaotic (and criminal), contradictions which remain even with the recent rise of a new sort of live music corporate oligopoly. From our perspective what matters is to understand that local, small-scale do-it-yourself promotion remains as necessary to the live music ecology as Live Nation et al. The exchange value of live music as a commodity, that is to say, is dependent on its use value as a particular kind of uncommodifiable experience.

\section{Notes}

1. See, for example, the work coming out of their current AHRC funded project, Popular Musicscapes and the Characterisation of the Urban Environment.

\section{References}

Anderson, Timothy J. 2006. Making Easy Listening. Material Culture and Postwar American Recording, University of Minnesota Press, Minneapolis MN. 


\title{
Constructing a Rough Account of British Concert Promotion History
}

\author{
Matt Brennan
}

m.t.brennan@gmail.com

\section{University of Edinburgh}

\begin{abstract}
This is the second of four related articles in this journal presenting findings from the first year of a research project on live music in the UK. A framework-in-progress is proposed which periodizes the history of British concert promotion since 1955. The first period of 1955-1969 is characterized by the absence of corporations and ancillary industries and the presence of entrepreneur concert promoters; the Musicians' Union reciprocal exchange; the impact of DIY music-making and youth-pop; the strain on concert promoting conventions by the growth of the pop market. The second period of 19691996 is characterized by record labels subsidizing tours to promote record sales; 'new' school pop promoters; the professionalization of ancillary industries catering to live music; and the development of the arena circuit. The third and final period of 1996-2009 is characterized by record sales losing 'wallet share'; ticket prices rising well above inflation; the rise of multi-national corporations entering the live music market; and a changing dynamic between the recording and live industries.
\end{abstract}

Keywords: live music, United Kingdom, UK, Great Britain, concert promotion, history, music industry, promoters, Live Nation.

\section{Introduction}

The live music research project introduced by Simon Frith in the first part of this series of articles aims to cover the history of British concert promotion from 1955 to the present day. As such, one of the biggest challenges for our research team is to conceptualize over fifty years of the rich and varied history of British live music, and how to best divide it into manageable chunks. In this article, I will present our initial attempt to construct an account of the development of British concert promotion, which we have tentatively periodized into three eras. These divisions are likely to change as we go further in our research, but they represent a first stab at giving some structure to what is, in reality, a very complex history that is resistant to having crude 'eras' imposed upon it. These divisions are therefore not meant to be definitive; however, there are some interesting characteristics in each period that endow the divisions with a certain kind of logic, which I will outline now. 


\section{1) $1955-1969$}

a) Absence of corporations and ancillary industries, concert promoters as entrepreneurs

One obvious difference between the live music sector in 1955 versus now is the absence at that time of corporate promoting entities and a professionalized sector of ancillary industries to live music (live sound engineering, ticketing, transport, etc.). Instead, we see the presence of a more informal network of venues, agents, managers, and promoters, with key individual entrepreneurial personalities leading the way. At the top of the promoting food chain were established promoters such as Harold Fielding and Harold Davison, who dealt with jazz, musical theatre, and jazz-based pop. There were also newcomer promoters, such as Larry Parnes and Arthur Howes, who capitalized on the burgeoning teen pop market. These larger, usually London-based promoters often worked with local promoters in towns across the UK to book shows. Promoters also often simultaneously acted as managers, agents, promoters, and labels for artists they worked with, which made the British music industry distinct from the US, where anti-trust legislation prevented taking on such conflicting roles (Boyd 2008).

\section{b) Musicians' Union reciprocal exchange}

There was also a completely different protocol for foreign musicians wishing to perform in the UK. Since at least the 1930s, the British Musicians' Union wielded a strong influence on the Ministry of Labour, and discouraged them from granting work permits to any American dance bands wishing to play in Britain unless a reciprocal agreement was in place where a British dance band would be sent to the US to perform in exchange. ${ }^{1}$ Since there was next to no demand for British jazz and pop in the US until much later, this meant that very few American artists performed in Britain until 1955, when reciprocal exchanges began to become more common. Even at the height of the British invasion in the 1960s, however, when there was actually demand in the US for British performers, the Musicians Union reciprocal exchange still had to be abided by, and affected whether touring bands could bring their own backup band or not.

c) Impact of DIY music-making and youth pop

The 1950s and 1960s period is characterized by an upsurge in amateur and DIY (Do It Yourself) music-making, in genres such as trad jazz, skiffle, folk, $R \& B$, and rock. With these genres came new kinds of venues and clubs that catered to each style, and the emergence of a pub gigging circuit. Pop groups also displaced dance orchestras, which for years had enjoyed residential contracts at ballrooms. Young audiences on a night out gradually went to fewer live dance orchestras, instead preferring to dance to DJs spinning records of popular artists or a mix of live bands and dance records. ${ }^{2}$ Concert promoters who proved unable to adapt to such changes risked commercial ruin, but those who remained flexible were able to reap rewards. Cliff Richard and the Shadows, one 
of the most popular acts performing 'teen-beat' music, sold out tours in record numbers, which were promoted by Arthur Howes. Cliff and the Shadows were one of the pioneering youth pop acts who began to tour in their own right rather than as part of a package tour, not least because they were able to perform sets without relying on a backup band.

d) pop's growing market strains concert promotion conventions

The growth in audience demand for appearances by pop groups like Cliff Richard, The Beatles, and other bands resulted in a shifting of the economic gateposts for the live music sector during this time. Pop managers were able to argue on behalf of their artists for increasingly better terms for concerts, and in the mid-1960s there are many reports in the music press of a growing tension between concert promoters and pop artists. ${ }^{3}$ Performers expressed dissatisfaction with promoters for using venues with inadequate facilities, advertising an artist when no booking had been made, and promising fees were in the post but which never arrived. Promoters, on the other hand, complained of bands not fulfilling contracts due to getting a record in the charts, ignoring their previous commitments, and signing up for better paying gigs elsewhere, as well as a general attitude of indifference by certain professional groups and their agents. The rapid growth of the pop concert market meant that existing norms of live music promotion - on structural, technical, and performative levels - were quickly becoming inadequate to meet market demand in the UK, and finding a solution was often a painful process of trial and error.

\section{2) $1969-1996$}

a) record labels subsidize tours to promote record sales

One solution to come into place was for an act's record company to take control of touring to fit in with album promotion, and 1969 is a year when one begins to notice reports of the dynamic between the recording industry and live industry changing, most noticeably in press releases of record labels subsidizing concerts and touring costs to promote record sales in Britain. And it is this change that we've decided to use to mark the beginning of our second period. Record labels had experienced a period of great growth in the 1960s, and were beginning to realize that they now had the cash flow to offer financial support to help their new signings perform and tour at a loss in the hopes that expenses would be recouped in future record sales. Labels like EMI and RCA started presenting free concerts to promote their new acts, and by 1970 the Marquee Club was booked every Monday night exclusively for record label promotion concerts. ${ }^{4}$ Over the next few years there are reports in trade publications about labels underwriting substantial costs of tours to break new and even established artists. 
b) 'new school' pop promoters (via student unions)

The music press in 1969 also has many reports about the emergence of a new touring circuit in colleges. An ad in Melody Maker at the beginning of the year placed by an agency called College Entertainment Limited, thanks a list of 67 social secretaries for their patronage, so this circuit was clearly taking shape prior to 1969 as well (MM 4 January 1969, p.20). Social secretaries were either appointed or elected student concert promoters at universities, and this development resulted in two things: 1) a new touring circuit that gave acts access to the very important college market, 2 ) a new route for the younger generation who were closely connected to the new rocket market to break into an industry in need of employees who were more directly in touch with their market (Jenner 2008). Some industry professionals who got their start as social secretaries include promoter Harvey Goldsmith, Chrysalis founders Chris Ellis and Terry Wright, and the Who and Rolling Stones tour manager Pete Rudge, although there are countless others.

c) professionalization of ancillary industries (sound/light, trucking, security, merchandise, ticketing)

As anyone who has seen footage of the Beatles playing Shea Stadium can attest, the equipment for used for sound, lights, transport, and other elements of a large-scale concert event were either non-existent or woefully inadequate by the time the Beatles abandoned touring in 1966. However, by the end of the 1960s and early 1970s bands were beginning to buy high-powered custom-built sound and light systems for use in American stadiums, which they would then sometimes use in much smaller town halls, converted cinemas, or slightly larger venues such as London's Empire Pool or Earls Court. ${ }^{5}$ Bands that couldn't afford to own their own high-end touring equipment, or who realized that such equipment was only needed when they were on tour for small parts of the year, created a demand for various ancillary industries to the live music sector, such as professional sound and lighting, trucking, and security. There was also a professionalization of merchandise such as $t$-shirts and programmes in the 1970s, which were sometimes the result of labels and managers co-opting and contracting illegal bootleggers who were often more successful and innovative in their band merchandising than the artists themselves (Colson 2009). Finally, companies such as Ticketmaster shifted some of the balance of power away from promoters as they took over the mechanics of ticket selling and increased revenue potential via booking fees and commission. Ticketmaster was founded in the US in 1976 and established its UK division in 1981, and was merely one example of a growing ticketing industry, which grew rapidly especially once the proliferation of credit cards and later internet sales made it easier to set up call centres and websites rather than individual box offices (Ticketmaster 2009; Latham 2009). But the first internet sale by Ticketmaster only occurs in 1996, which brings us to our third period, and which l'll discuss in a moment. 
d) the development of the arena circuit

Another key development during this period was the building of arenas that could be used for pop concert events. Unlike America, where bands had been touring arenas and stadiums since the Beatles in the mid-1960s, few similarly adequate venues existed in most British cities apart from London (and by 'adequate' I don't mean acoustic improvements or audience enjoyment, I mean capacity to cope with ticket demand). Even in London stadium gigs started much later than in the States, with the first pop gig at Wembley Stadium being a 1972 rock'n'roll revue with Bill Haley and Little Richard (MM 22 July 1972, p. 33). Appropriately sized and equipped venues outside of London were few and far between, until gradually throughout the late 1970 s to the early 1990 s, a workable arena tour circuit emerged, with key venues including the The NEC Birmingham (1976), the SECC in Glasgow (1985), The GMEX in Manchester (1986), and the Sheffield Arena (1991). The advent of indoor arenas meant that bands could tour in the UK using similar equipment, standards, and economies of scale that they did in the US. Most importantly, whereas before a band might have to play two shows a night for two nights at a town hall, they could now play one night at an arena for half of the labour and hire costs, making more money, more efficiently, and thus growing the live sector (Latham 2009).

e) professionalization of promoters

Throughout the 1970s and 1980s, concert promoters themselves also showed signs of increasing professionalization, if only in an attempt to more effectively lobby government and other areas of the industry. In 1986, the Concert Promoters Association formed in response to an attempt by the Performing Right Society to treble their fees for live pop concerts, prompting promoters to collectively and successfully take action (CPA 2008). Similarly, the International Live Music Conference, which takes place in London and is the most important live music industry event in the world, was formed in 1988, 'according to one source, 'because agents thought they were going to be pushed out of the business' and agents used the ILMC to strengthen their collective voice (Latham 2009). Finally, in 1989 a live music industry trade paper called Applause was founded, where none had existed before, once again hinting at an industry that was beginning to become more publicly visible and coherent, with concert promoters beginning to shed, at least on the surface, what Keith Negus described as a 'bad reputation in the past for being aggressive wheeler-dealers, making excessive profits, and occasionally running off with the takings' (Negus, 1992, p. 130).

\section{6-present}

a) records begin to lose 'wallet share'

The first factor in the third period of British concert promotion has to do with the recording industry rather than the live industry per se. Key dates often 
cited in the digital period of the British record industry are 1999 when Napster was created, or 2001 when broadband arrived in the UK and peer-to-peer filesharing began to take off in Britain. However, in a recent article by Will Page, the chief economist of the PRS, he argues that in fact the key year for shifting patterns in music consumption is actually 1996. According to Page, this is when recorded music begins to lose its 'wallet share,' which 'refers to the proportion of disposable income that people devoted to buying music recordings' (Page 2007). He demonstrates that "recorded music's 'wallet share' of disposable income has actually been falling since as far back as 1996", meaning that record labels were getting increasingly less of the consumer's wallet than they did, "despite this trend taking root during a period of uninterrupted economic expansion" (ibid.). More interestingly, the fact that this downward trend predates the advent of broadband in the UK by 5 years "offers a rebuttal to claims that piracy is the sole culprit of the record industry's current woes" (ibid.).

b) ticket prices begin to rise well above inflation

As I mentioned earlier, Ticketmaster's first internet sale occurs in 1996, but meanwhile, another equally interesting change in ticket-selling starts in this year. Economists Alan Krueger and Marie Connolly (2005) demonstrate that 1996 is the point when concert ticket prices begin a period of rapid growth: "from 1981 to 1996 , concert prices grew slightly faster than inflation [... However,] from 1996 to 2003, concert prices grew much faster than inflation" (ibid.).

c) the rise of SFX, Clear Channel, and Live Nation

1996 was also the year the American Robert Sillerman and his company SFX Entertainment began acquiring companies in the live music sector, although he would not acquire any British companies until he bought three of the most significant promoters and venue operators in the UK in 1999 (Apollo Leisure Group, Midland Concert Promotions, and the Barry Clayman Corporation), making the American-based SFX one of the biggest players in the British live music landscape virtually overnight (Funding Universe 2009). In 2000, SFX was bought by the multi-national corporation Clear Channel, which then spun off its live entertainment assets into a separate company, Live Nation, in 2005. In a very short space of time, then, Live Nation has become the most important concert promoter in the UK as well as the second biggest music company in the world, larger than any of the major record labels apart from Universal.

d) changing dynamic between the recording and live industries

The decrease in revenue from recorded music, rise in ticket prices, and deeper pockets of multi-national promoters have yielded interesting developments, such as reunion gigs by many bands who had been inactive for years to cash in and buoy themselves against decreasing income from record sales. It's also meant a noticeable growth in the number of summer music festivals, which despite experiencing a contraction this summer due to a mix of over-saturation last year and the recession, are still at their most plentiful in the 
history of British music. In 2008, consumer spending on live music is reported by several sources to overtake spending on recorded music in the UK (Mintel, 2008; Page, 2009). Despite the actual value of the live music sector being hard to measure and a contraction in the past year, it remains safe to say that the dynamic between the recorded and live industries is changing and that it's no longer clear which revenue stream in pop music is now dominant (revenue from branding, syncing, and merchandise should also be considered in this debate).

\section{Conclusion}

In this very condensed periodization of the history of British concert promotion, I haven't had time to mention many important elements such as the role of radio and $\mathrm{TV}$, dancing and discotheques, the rise of corporate sponsorship, and countless other factors. Indeed, one could argue for a different set of historical emphases and different division points-and therefore an alternative construction of the history of the British live music from 1955-2009. On the one hand, our team is conscious of Keith Negus's suggestion that 'musical history making cannot be known in any innocent sense. Arranging a vast number of sounds, words and images into musical "eras" is not a neutral activity. It involves a process of imposing patterns and order onto the many events taking place across space and through time' (1996, p.138). On the other hand, constructing historical eras, regardless of their artificial nature, can be a necessary and potentially useful method to make sense of an inevitably complex and often unwieldy wealth of historical data.

This article has described many changes in the history of British concert promotion, and their impacts on the UK's live music culture are varied. However, one of our project's aims to also reveal what characteristics have held the British live music sector together over time. Take, for instance, the following quote from promoter Harvey Goldsmith:

"The music Radio One is playing has no relation to the current live trends. Absolutely zero. For the up-and-coming acts, life is becoming increasingly more difficult. [...] The Rolling Stones [...] they're still pulling the crowds in. [... But] there are too many shows on the road, and I don't think the market can take it. I can foresee a slump in the concert business. [...] The new acts don't seem to be paying dues anymore. One hit record and they're already headlining their own tour. They're being pushed too hard and too fast. And not enough good ones are coming through. I think this is the fault of the record companies. The companies are holding back to a man, and going through a very strange phase-they're not finding new acts. [...] The companies are cutting out what they used to do on promoting acts. They're just saying 'If they don't sell records, 'well drop 'em.' And this is reflected at our end of the business" (quoted in Partridge, 1974, p.8). 
Goldsmith's comments could have come from any number of industry pundits in 2009 , but in fact the quote is from 1974. As much as our historical research is charting changes in the live music sector, it's also revealing what appear to be recurring themes in the discourse of the industry. As our research progresses, we hope that an account of the industry's past will be useful not only as a document, but also in illuminating and analysing its present condition.

\section{Notes}

1. Jim Goldbolt (1989) has written more than any other on the impact of the Musicians' Union on the live music sector, although our research team is currently conducting more research to investigate this history.

2. In 1959, for instance, the Association of Ballrooms, which represented over 140 ballrooms across Britain, began to formally work with the Musicians' Union against the perceived threat of 'disc hops' (MM 6 June 1959, p.1).

3. See MM, 28 November 1964, p.5; MM 9 October 1965, p.4; MM 8 January 1966, p.3; $\quad$ MM 9 July 1966, p.8-9; MM 11

February 1967, p.20; MM 13 February 1966, p.4; MM 17 September 1966, p.25; MM 28 January 1967, p.8.

4. See RR 4 June 1969, p.2, 16 July 1969, p.13, RR 2 May 1970, p. 2.

5. See MM 12 September 1970, p.36; MM 25 September 1971, p. 1; MM 22 July 1972, p.9; MM 19 August 1972, p. 5; MM 19 August 1972, p.24.

\section{Acknowledgements}

This article is part of a larger project examining the promotion of live music in the UK, and is funded by AHRC research grant F00947/1.

\section{References}

Boyd, Joe. 2008. Interview with Matt Brennan in London, 7 November.

Colson, Gail. 2009. Interview with Matt Brennan in London, 4 June.

Concert Promoters Association. 2008. Press release supplied by Carole Smith, CPA secretary.

Connolly, M. \& Krueger, A. 2005. "Rockonomics: The Economics of Popular Music", working paper. <http://www.krueger.princeton.edu/working papers.html> [Accessed 15 July 2009]

Funding Universe. 2009. "SFX Entertainment Inc.", 22 January $<$ http://www.fundinguniverse.com/company-histories/SFX-Entertainment-IncCompany-History.html > [Accessed 15 July 2009] 
Godbolt, Jim. 1989. A History of Jazz in Britain: 1950-1970. London: Quartet. Jenner, Peter. 2008. Interview with Matt Brennan in London, 11 November. Latham, Paul. 2009. Interview with Matt Brennan in London, 3 June.

Melody Maker. 1959. "Ban these Disc Hops - Say Ballroom bosses”, 6 June, p.1. Melody Maker. 1964. "Club promoters to combine", 28 November, p. 5. Melody Maker. 1965. "Walkers quit the ballroom scene", 9 October, p. 4. Melody Maker. 1966. "Perils of Pop -and the shady men on its fringes", 7 July, p. 8-9.

Melody Maker. 1966. "Ballroom row”, 13 February, p. 4.

Melody Maker. 1966. "Northern promoters attack pop groups", 17 September, p. 5.

Melody Maker. 1966. "Stones States gates dismal", 16 July, p. 6.

Melody Maker, 1966. "Time to move on from the ballrooms", 8 January, p. 3.

Melody Maker, 1967. “Are All Promoters Angels?”, 11 February, p. 20.

Melody Maker. 1967. "Who would be a promoter?", 28 January, p. 8.

Melody Maker. 1969. "College Entertainments Limited", Advertisement, 4 January, p. 20.

Melody Maker. 1970. "2,000 watts of Who Power'”, 12 September, p. 36.

Melody Maker. 1971. "Who Go Heavy”, 25 September, p. 1.

Melody Maker. 1972. "Garden party at crystal palace bowl", Advertisement, 22 July, p. 9.

Melody Maker. 1972. “Garden Party V”, Advertisement, 19 August, p. 5.

Melody Maker. 1972. "The Rock 'n' Roll Show”, Advertisement, 22 July, p. 33.

Music Week. 1973. “£20,000 Barclay James Harvest promotion”, 3 February, p. 3.

Music Week. 1973. "Bowie LP drive on”, 24 March, p. 1.

Music Week. 2009. "UK live revenues surpass record sales", 17 March, $<$ http://www.musicweek.com/story.asp?storycode=1037247> [Accessed 15 July 2009]

Negus, Keith. 1992. Producing Pop: Culture and Conflict in the Popular Music Industry, Edward Arnold.

Negus, Keith. 1996. Popular Music in Theory. Cambridge: Polity. 
Page, Will. 2007. "Economics: Time to Face the Music", Music Ally, 18 October, pp.7-8.

Partridge, Rob. 1974. "Business-we're heading for a slump...", Melody Maker, 21 September, pp.8-9.

Prynn, Johnathan. 2008. "Festival explosion turns live music into $£ 1.9 \mathrm{bn}$ big business", Evening Standard, 10 September, $<$ http://www.thisislondon.co.uk/standard/article23553561details/Festival+explosion+turns+live+music+into+1.9bn+big+business/ article.do> [Accessed 15 July 2009]

Record Retailer. 1969. "2,000 at first EMI Harvest Free Concert", 4 June, p. 2.

Record Retailer.1969. "RCA books Lyceum for promotion concert", 16 July, p. 13.

Record Retailer. 1970. "Promotion showplace", 2 May, p. 2.

Ticketmaster. 2009. "Company History", 22 January.

$<$ http://www.ticketmaster.com/history/index.html > [Accessed 15 July 2009] 


\title{
Live Music and Music Policy: Some initial thoughts
}

\author{
Martin Cloonan \\ M.Cloonan@music.arts.gla.ac.uk
}

\author{
University of Glasgow
}

\begin{abstract}
This is the third of four related articles in this journal presenting findings from the first year of a research project on live music in the UK. It presents some initial findings and reflections upon the impact of live music on music policy.
\end{abstract}

Keywords: live music, music policy, regulation.

\section{Introduction}

This paper draws on research which has been conducted as part of the live music project, on my own longstanding interest in the regulation of popular music and also on my recent experience as a band manager. It differs from the AHRC project in that whereas that covers all genres of music my focus here is more narrowly on popular music. I want to tease out some of the policy implications of researching live music and do so by examining three key areas.

1. The necessity of regulation

2. Live music and the black economy

3. The impact of technology on ticketing

I want to argue that live music has direct policy implications for which are not present with recorded music. As such it presents a potentially rich field of research for those of us who are interested cultural policy and regulatory frameworks.

I should note before I begin that this paper draws upon work done for the project by the rest of the team and particularly interviews conducted by Matt Brennan and Emma Webster. So l'd like to acknowledge their contribution while taking full responsibility for the arguments in the paper. 


\section{Part One: The necessity of regulation}

It is noticeable that live music has received much less academic attention that recorded music has, especially in terms of its industrial structure. But another noticeable thing is that when live music has received attention it has been in terms of issues concerning its regulation - thus in the early 1980s Michael Clarke wrote a book on focussed on free festivals and the problems they were having (Clarke, 1982). In 1991 Paul Chevigny documented the way in which local bylaws had virtually banned jazz from parts of New York, and my own work on censorship and music in the UK in 1996 featured accounts of how regulation could act as a form of censorship. In 2003 Shane Homan's first book documented the way in which Sydney's local music scene was mediated by regulations or the lack thereof. So there is something of a tradition of academic work on live music concentrating on regulation and thus on policy. In order to illustrate this I now want briefly to address four more areas - flyposting, the 2003 Licensing Act, the importance of locality and Form 696.

The regulatory framework around live music begins even before a gig has started. Here perhaps one of the most contentious issues in recent years has been advertising of gigs by flyposting and/or flyering. As part of our research we're interviewing promoters and one of the issues which has come up is the attitude of local authorities towards this issue. Sheffield promoter Alan Deadman told us that:

....there's no poster-boards. I think in many respects that's got worse . . . It's almost like a neo-fascism... where cities think that in order to attract investment, people to relocate there, they have to have a squeaky clean city' (Deadman, 2008).

Similarly Mark Mackie of leading Scottish promoter Regular Music reported that:

The police came up here and gave me a warning about some fly posting l've been doing,... Edinburgh's got its head in the sand, right? Glasgow met the problem head on and has official fly posting sites now that are cleaned up and tidied, and the drums - and they're working a treat' (Mackie, 2008).

Elsewhere it was reported that Newcastle has had 'a well-earned reputation for vociferously pursuing people flyering from local venues' (Mean and Times, 2005, p. 6) and that Liverpool Council has also taken action against flyposting despite the fact that 'many music venues depended on fly-posting as their main source of advertising, even though it was often in breach of the law' (Cohen, 2007, p. 204).

This sort of action can alienate live music promoters and a DEMOS report suggested that compromises such as having designated spaces for flyposting are necessary and that 'Ideally there should be no restrictions on flyering in the street' (Mean and Times, 2005, p. 22). 
In terms of licensing live music in England and Wales is described within the law as being a form of regulated entertainment which therefore requires a licence (Frontier, 2007, p. 5). In fact live music has implications for regulatory authorities which are not present in recorded music. In part this is because the provision of live music generally automatically raises a set of health and safety issues which are not present with recorded music. These include issues of health and safety, but also, importantly, rules concerning the consumption of alcohol.

So once we get to the gig itself a key area is licensing. Under the 2003 Licensing Act for England and Wales, the provision of live music is applied for at the same time as an alcohol licence. A copy of the licence application goes to the following bodies: the chief of police, the fire authority, the health and safety authority, the local planning authority, the environmental health authority, the body recognised as being responsible for protection of children from harm, and Inspectors of Weights and Measures (trading standards officers) (Callahan et al 2006, A3).

In addition the application must be advertised on the proposed premises and in a local newspaper in order to bring it to the attention of "interested parties" who are able to make representations to the licensing authority. These parties include: People living in the vicinity of the premises, Bodies representing people living in the vicinity of the premises (e.g. residents' groups and parish councils), People involved in a business in the vicinity of the premises, Bodies representing persons involved in these businesses (e.g. trade associations) (ibid).

As I understand the law, it is possible for such parties to make representations against the provision of live music, but not in favour of it. But my point is not to bemoan bureaucratic "red-tape" as I recognise the necessity for most of this. The point is that the provision of live music automatically involves a high degree of regulation and the 2003 Act has been a key area of policy.

The Act came into force in November 2005 and many problems concerned small scale gigs. Under the previous regime up to two musicians could play in pubs without the venue needing a live music licence, under the so called "two in a bar" rule. But under the new legislation all music events needed a licence with the only exception of up to twelve Temporary Events per annum. Many musicians and small scale promoters were concerned that the new requirement of a licence for all gigs combined with the potential cost of the application, would lead to a decline in the amount of venues putting on live music.

In response the Government set up a Live Music Forum in 2004 to monitor the impact of the Act. This it did as well as producing a number of documents and reports (MORI 2004; Hanson et al 2007; Callahan et al, 2006; LMF, 2007). The Forum's final report found that contrary to government claims in advance of the legislation that it would result in a boom in live music, the overall impact was broadly neutral. It called for a loosening of the legislation and was backed in this by a Culture, Media and Select Committee (2009) Report. ${ }^{1}$

Overall the 2003 Act has been an example of government policy in one area - alcohol - having a perhaps disproportionate effect in another - live 
music. ${ }^{2}$ This is symptomatic of a broader phenomena whereby the most important policies for music are not about music but about creating the sorts of places where musicians want to live (Frith et al 2009, p. 83).

The Act has also shows that importance of local interpretation by Licensing Authorities. Thus Sheffield promoter Mark Hobson told us that:

I think there's . . a policy in Sheffield that's not written down. That has been devised by the police, licensing, and Child Protection.. to interpret the . . . licensing reform in a way that they feel is appropriate, which is control, as opposed to opening it up. They want to restrict rather than open up, and they're viewing it in that way' (Hobson, 2008).

Perhaps the most notorious recent example of local intervention is the Metropolitan Police's Form 696. This is a "risk assessment" form which has been approved by all of London's councils. It used by the Metropolitan police in instances where trouble is expected at a gig or club. It asks for all performers names, address, date of birth and phone number. At one point it included details of any particular ethnic group which might be expected to attend, although this was later dropped. But it still includes details of which style of music is being performed. It has to be with the police 14 days before an event and venues are also required to fill out form 696A which provides an "event debrief".

According to Music Week (6 July 2009) it covers over 100 venues all of which face the risk of a $£ 20,000$ fine if they fail to comply (Music Week 23 March 2009). It has been reported that eight shows have been cancelled by promoters following discussions with the police (Youngs, 2009). The form was criticised by the the UK Parliament's Culture, Media and Sport Select Committee which called for it to be scrapped, as has UK Music and the Musicians' Union. As of July 2009 the form was under review (Ashton, 2009), but its very existence again shows the importance of local regulation.

To summarise, l've suggested that local regulation of the ways gigs are advertised and of the licensing process are two key areas for policy, but I now want to suggest that as part of the night time economy live music is inherently somewhat shady.

\section{Part Two: The black economy}

Here we see something of a paradox, because this section will show that while it is heavily regulated, live music is also simultaneously one the least regulated parts of the music industries. In part this is because it is generally part of the night time economy, aspects of which are notoriously hard to regulate. For example, Shane Homan's (2003) account of Sydney has more than its share of dubious goings on.

Of course this has a long history. Back in the UK, referring to those who ran London music clubs in the 1960s, former Pink Floyd manager Pete Jenner 
noted that the clubs 'were often controlled by very dubious people with broken noses' closely connected to criminals such as the Krays. He said that:

I'm sure they were dealing drugs, they were very dodgy people, you didn't fuck with them. And a lot of these pub rooms were run by very dodgy people, and lots of them became respectable (Jenner, 2008).

$\mathrm{He}$ also spoke of a number of eminent figures who were 'really dodgy') $\mathrm{He}$ described a "barrow boy tradition" and believed that 'I'm sure a lot of the promoters in the 1950s were what were called "spivs" in the 1940s, and selling black market gear' (ibid.).

Another immediately striking thing about live music as an industry is how much cash is floating about, especially at the local level. We have been repeatedly informed off the record that promoters routinely operate swindles such as charging an act of putting up 1,000 posters but only putting up 500 and pocketing the cash. Or think about how you determine how many tickets have been sold - a key task for any decent tour manager. Add to this the anarchy of the merchandise table - who knows who is selling what and how much is being sold and then consider the army of "Hangers on" - touts, but also illicit/unofficial t-shirt/poster etc sellers. Consider all this and more and it becomes clear to me that live music is incredibly regulated and un-regulated at one and the same time.

Because of the prevalence of cash Jenner told us that despite some professionalisation in recent years live music was 'still dodgy':

\begin{abstract}
Absolutely. Absolutely it's still dodgy. Any business which involves lots of cash is dodgy. How do you become successful in this business? Basically, if you can get away with not paying as much as you really ought to be paying, and underestimate your income for the sake of the taxman, you can increase your profitability. That requires a certain level of deviousness, a certain ambiguity towards one's liability to the state and your client. The oldfashioned, do you deal with people in an honest way or a dishonest way? So the people who deal in a dishonest way but can appear to be honest, do very well (ibid.).
\end{abstract}

Even in the more legitimate world things are somewhat opaque. For example, songwriters are meant to be paid for having their songs played in public via fees to the PRS, which is meant to receive $3 \%$ of the price of a gig ticket price. The promoter should sign off a list of songs performed by the acts which is then forwarded to PRS which distributes the monies collecting to the songwriters. But it is not in the promoter's interest to sign the form and it often doesn't happen even, in my experience, at major festivals. And of course, as musicians' incomes from recording is generally in decline this revenue is increasingly important, but on a less than perfect system.

It has also struck me that while the UK has minimum wage legislation this does not appear to apply to live music. Many bands don't get paid for playing and if they do I would guess that this would often be low and the total amount of 
hours spent at the gig including sound checks would leave most musicians earning well below the minimum wage.

There is also the question of what age people can go to gigs and recently deliberate attempts have been made to promote over $14 \mathrm{~s}$ shows. But again local licensing authorities have discretion and we heard complaints in Sheffield about the Council making it hard to put on over $14 \mathrm{~s}$ shows and the police trying to con venues into selling alcohol to under 18s (Wilson, 2008).

We've also heard strong allegations of anti-competitive practice in our own city of Glasgow and it is noticeable that no new big promoters have emerged in recent years. A sense of collusion in stifling new promoters has been asserted. This is enhanced by the fact that ownership patterns in the live music industry are incredibly complex with companies owning bits of each other or forming joint ventures to buy into competitors in ways which appear to be designed to circumvent legislation on monopolies.

To summarise this section, I've suggested that historically the promotion of live music was allied to certain forms of "dodgy" behaviour. Overall live music is still characterised by a great deal of informality and illicit practice. This will be continued when I move to my final area.

\section{Part Three: The impact of technology on ticketing}

Ticketing has been transformed by the internet. The availability of tickets "24/7" has transformed that market at a time when live music itself has become an increasingly important part of the political economy of the music industries. Here I want to concentrate on one issue which has received a lot of attention secondary ticketing.

Put simply, secondary ticketing is a form of activity whereby a person or organisation buys tickets for an event and then sells them on to a third party. This can range from someone buying tickets and then finding they can't go up to organisations which make their income from selling on tickets in a myriad of ways. In the former instance one impact of the internet and ebay is that we have "bedroom touts" - something which can be very lucrative (Robinson, 2008b). But what should government policy be in such areas? Much depends here on how you view the ticket itself - is it a piece of property or an entitlement?

The implication of the ticket being a piece of property is that the purchaser can sell it on as they could, for example, a book or can of beans. With certain exceptions - most notably around football and, separately (if relatedly) the Olympic games - this is the legal situation in the UK. The "right" to sell tickets on has been most vociferously put forward by the secondary ticket agents who generally argue for a free market.

A contrary case was initially put forward by the Concert Promoters Association (CPA), other primary agents and the major sporting bodies. The argued that tickets are an entitlement granted under certain conditions - one of 
which is that the ticket is not sold on. Unfortunately it appears that this has not been tested under UK law and it may be the case the ID schemes for tickets are illegal.

Here I want to make the point that while issues of illegal downloading have attracted most attention, in essence the record companies' response was to try to exert and extend existing copyright law. But in the case of live music the government was being asked not to re-assert to intellectual property rights, but to arbitrate about the nature of property itself.

At first the CPA launched a campaign to have secondary ticketing or touting outlawed. It enlisted the support of John Robertson MP, Chair of the AllParty Music Group, who called for a ban on touting which he described as 'simply extortion at the expense of both fans and the entertainment industries' (Guardian 15 January 2008, p.33).

However the government was saved from a difficult decision in March 2008 when the CPA dropped its opposition to the secondary market and said that it now supported effective regulation rather than a ban on touting (Robinson, 2008a).

In fact the writing had been on the wall a little earlier because of the actions of one key primary ticket seller - Ticketmaster. This company told the Culture, Media and Sport Select Committee in June 2007 that: 'We would like to see the legislation which is there for football and for the Olympics being extended... into other sports and music events' (Hansard, 2007).

Having made this noble stand against the secondary market, in January 2008 Ticketmaster bought the secondary ticket agency GetMeln.com. Its excuse was that of bringing legitimacy and security to the secondary market (letter from Chris Edmonds, MD of Ticketmaster to Guardian 5 June 2008). ${ }^{3}$ In effect Ticketmaster's acquisition of GetMeln blurred any distinction between primary and secondary agents.

This view was vindicated in March when it was revealed that the promoter AEG had sold Michael Jackson tickets with a face value of $£ 50$ and $£ 75$ to the secondary ticket agency Viagogo to sell on as $£ 500$ "premium" tickets. Between 500 and 1,000 tickets each night of the 45 scheduled shows were said to be sold in this way with AEG collecting $80 \%$ of the income (Foster et al, 2009). The CPA has now introduced its own exchange site - officialboxoffice.com and its chair, Rob Ballantine, now accepts that 'touting is inevitably here to stay' (Anon, 2009).

Meanwhile in order to discern what to do here in February 2009 the Government published a consultation document (DCMS, 2009) with the consultation ending on 15 May and the results currently awaited. The Government has sought to establish best practice, rather than outlawing. Its preferred option is the establishment of a Code of Principles, the extension of ticket exchange services and - in an allusion to what was mainly a problem for sports - a market based approach to events of national significance. 
To a certain extent the climbdown by the CPA has let the government off the hook, but the question still remains as to what government policy should be on the secondary market for concert tickets - should the emphasis be on property rights or cultural value? What should policy be here?

More broadly via new technology the issue of concert tickets led to a situation where the government was asked to choose between different conceptions of property. The fact that ultimately it was able to get away with not choosing may owe more to an economic downturn and the ever opportunistic behaviour of promoters, than it does to profound philosophical or even economic thinking. Nevertheless while the downloading of recorded music may have got more headlines, it is the political economy of live music which offered more profound challenges to property law.

\section{Conclusion}

What I hope to have done in this paper is to outline what a rich area live music is for research in policy. I've noted three key areas - regulation, the allied question of the black market and finally the way in which changing technology has created new questions about a key part of the live music industry - that of ticketing. Live music remains under-researched within Popular Music Studies and more broadly. I suggest that this needs to change and hope to have least provided some food for thought for why it should.

\section{Notes}

1. It should also be noted that the Wiltshire police used section 160 of the 2003 Act which deals with potential disorder as a reason to ban Babyshambles from appearing at the Moonfest festival (Culture, Media and Sport Committee, 2009: Ev. 151).

2. For guidance on the empirical effects of the Act see Kemp et al (2009, 10-5-13).
3. Note that the links between primary and secondary market has always been close as Pete Jenner told us of an eminent promoter from the $1960 \mathrm{~s}$ who used his brother to tout tickets, something which he claimed promoters have always been doing.

\section{Acknowledgements}

This article is part of a larger project examining the promotion of live music in the UK, and is funded by AHRC research grant F00947/1. 


\section{References}

Ashton, Robert. 2009. "London police set to review 696", Music Week online 1 June 2009, <www. musicweek.com/story.asp?storycode=1037828> [Accessed 10 May 2010]

Callahan, C., Martin, A. \& Pierce, A. 2006. Licensing Act 2003: The experience of smaller establishments in applying for live music authorization, DCMS, London.

Chevigny, Paul. 1991. Gigs: Jazz and The Cabaret Laws in New York, Routledge, New York.

Clarke, Michael. 1982. The Politics of Pop Festivals, Junction Books, London.

Cloonan, Martin. 1996. Banned! Censorship of Popular Music in the UK 19671992, Arena, Aldershot.

Cloonan, Martin. 2009. Promoting Pop: A Guide for Regional Development, report commissioned by PASCAL, PASCAL, Glasgow.

Cohen, Sara. 2007. Decline, Renewal and the City in Popular Music Culture: Beyond the Beatles, Ashgate, Aldershot.

Competition Commission. 2007. Hamsard and Academy Music: a report on the proposed acquisition of a controlling interest in Academy Music Holdings Limited by Hamsard 2786 Limited, Competition Commission, London.

Culture, Media and Sport Committee. 2009. The Licensing Act 2003, Sixth Report of Session 2008-09, The Stationery Office, London.

Deadman, Alan. (2008) Interview with Emma Webster, 19 August 2008

Department of Culture, Media and Sport (DCMS). 2009. Consultation on Ticketing and Ticket Touting, DCMS, London.

Electric Blanket (2008) Interview with Emma Webster 21 August 2008

Foster, P., Sabbaghm, D. \& Sherwin, A. 2009. “£500 for Michael Jackson comeback show tickets as promoter in secret deal", Times online 12 March 2009, $<$ http://entertainment.timesonline.co.uk/tol/arts and entertainment/music/article5 891378.ece> [Accessed 10 May 2010]

Frith, S., Cloonan, M. \& Williamson, J. 2009. "On music as a creative industry" in Andy Pratt and Paul Jeffcott (ed.) Creativity, Innovation and the Cultural Economy, Routledge, London, pp.74-89.

Frontier Economics (2007) The feasibility of a live music impact study, DCMS, London.

Hancox, Dan. 2009. "Public enemy no 696”, Guardian, 21 January 2009, part two, pp.24 
Hansard (2007) Report, $<$ www.publications.parliament.uk/pa/cm200607/cmselect/cmcumeds/uc767/uc76 702.htm> [Accessed 2 Feb. 2010]

Hanson, T., Hayward, B. \& Phelps, A. 2007. A Survey of Live Music in England and Wales 2007,DCMS, London.

Hobson, Mark. 2008. Interview with Emma Webster, 21 August 2008.

Homan, Shane. 2003. The Mayor's A Square: Live Music and Law and Order in Sydney. Local Consumption Publications, Newtown.

Jenner, Pete. 2008. Interview with Matt Brennan, 11 November 2008.

Johnson, B. \& Homan, S. 2002. Vanishing Acts, Council/NSW Ministry for the Arts, Sydney, Australia.

Laing, Dave. 2008. Interview with M. Brennan, 10 November 2008.

Live Music Forum. 2007. Findings and Recommendations, DCMS, London.

Mackie, Mark. 2008. Interview with Emma Webster, 1 July 2008.

MORI. 2004. A Survey of Live Music Staged in England and Wales in 2003/4, DCMS, London.

Office of Fair Trading (OFT). 2005. Ticket Agents in the UK, OFT, London.

Razor, Ralph. 2008. Interview with Emma Webster, 19 August 2008.

Robinson, James. 2008a. "Promoters change tune on touts", Observer, 9 March 2008, business section, p. 2.

Robinson, James. 2008b. "Ticket touting beats stock market every times", Observer 11 May 2008, business section, p.1.

Sharratt, Tom. 1994. “Gunman kills bill poster”, Guardian, 4 May 1994, p. 2.

Weales, S. \& Sharratt, T. 1994. "Price of trespassing on rival's turf paid in blood", Guardian, 4 May, 1994, p. 2.

Williamson, J. \& Cloonan, M. 2007. "Rethinking the music industry", Popular Music, 26:2, pp. 305-322.

Wilson, Chris. 2008. Interview with Emma Webster 21 August 2008.

Youngs, lan. 2009. "Police defend concert crackdown", BBC News online 19 May 2009, <http://news.bbc.co.uk/1/hi/entertainment/8053629.stm> [Accessed 10 May 2010] 


\title{
King Tut's Wah Wah Hut: initial research into a 'local' live music venue
}

\author{
Emma Webster \\ emmaswebster@gmail.com
}

University of Glasgow

\begin{abstract}
This is the fourth of four related articles in this journal presenting findings from the first year of a research project on live music in the UK. This article provides a "thick" description of a Glasgow venue - King Tut's Wah Wah Hut - to illustrate how a small, local venue fits into the local, national and global live music industries as described by Simon Frith and Matt Brennan, and within the local/national government regulations as described by Martin Cloonan. By also considering the venue's necessary understanding and control of the social interactions between artist and audience, the article illustrates issues faced by many venues and promoters in the UK.
\end{abstract}

Keywords: live music, United Kingdom, UK, Great Britain, Glasgow, ethnography, King Tut's, concert promotion, history, music industry, promoters, Live Nation.

\section{Introduction}

The role I have within the project is to undertake contemporary research into live music, with the aim of learning more about how promoters and venues understand the music-based experiences that they seek to persuade their audiences to enjoy. This paper will share some of the initial findings from research carried out in May and June 2009 at King Tut's Wah Wah Hut in Glasgow, Scotland, which is one of a number of venue case studies being carried out in Glasgow, Sheffield and Bristol. This paper will build on Simon Frith's 2007 article on why live music matters, by exploring the following: firstly, how King Tut's fits into the larger structure of its parent company - DF Concerts - and the national and global live music industry as a whole, building on Matt Brennan's work on the current shape of the live music industry. The second section will offer a brief examination of how the venue adheres to local and governmental 
regulations to further illustrate Martin Cloonan's work on the policy implications of researching live music (2009). Finally, the third section will look at how the social interaction between the artist and the audience is understood and controlled by the venue, and how the venue understands and meets the expectations and requirements of its audiences and functions accordingly.

Drawing on and inspired by Ruth Finnegan's 1989 work on the hidden musicians of Milton Keynes, the methodology was as follows: in-depth interviews with venue staff were carried out, including the bar manager, and a promoter's representative; mini-interviews with audience members, focusing on their motivations for attendance and audience behaviour; an ongoing online questionnaire; and participant observation over thirteen nights.

\section{A brief introduction to King Tut's Wah Wah Hut}

To begin, some background about King Tut's Wah Wah Hut: King Tut's is a three hundred capacity music venue with a bar attached, with live music on every night of the week (apart from quieter periods in the summer months). The venue is owned and managed by Scotland's largest live music promotion company, DF Concerts, which is currently the only promoter using the venue. The venue itself consists of a long, narrow downstairs basement bar through which is accessed the music venue on the level above, with the backstage area above the venue and the DF Concerts headquarters upstairs from this. The venue is housed in a Georgian terraced building, surrounded by office buildings and residential properties, and, whilst within Glasgow city centre itself, is considered by those who work there to be 'off-the-beaten-track'; it is at least a five minute walk from the nearest entertainment hub - Sauchiehall Street - which is home to bars, clubs and other music venues. The venue opened as King Tut's Wah Wah Hut in February 1990 and is famously (allegedly) the place where Alan McGee spotted Oasis in 1993 and signed them to Creation Records. Radiohead and The Verve also played in 1993 and BBC Radio One pronounced King Tut's as the "Best Launch Pad Venue 2000" and the "UK's Best Live Venue" in 2002 (King Tut's Wah Wah Hut website, 2009).

During the research period at King Tut's, a diverse range of musical genres was experienced, including metal, rock, indie, grime, techno, and acoustic folk. This diversity highlights King Tut's relative flexibility in terms of the musical genres it can cater for, and that the venue is not aligned to any one particular subculture or genre. This is also reflected in the age range of its attendees: from over-14 year-olds (over-14s) for certain shows all the way up to 70 year-olds for the weekly Saturday matinee jazz gigs. The musical programme generally includes a mixture of local, up-and-coming artists and 'larger' artists, such as The Breeders, Idlewild and The Beat, and ticket prices are between approximately $£ 5$ and $£ 15$. 


\section{A 'local' venue within a global live music industry}

Using Pete Webb's 2007 work on a theoretical matrix to explore the networked worlds of popular music, King Tut's could be seen to operate within firstly, the local milieu, secondly, Bourdieu's "fields of cultural production" - in this case, the live music industry - and thirdly, the relationships that the first two levels have with other milieu, including local and national culture, economy and politics, and global culture, economy, and politics. Using this framework, King Tut's operates as a local venue, owned by a national promotional company that works throughout Scotland and within local and national regulatory frameworks. King Tut's and DF Concerts also operate within a global live music industry, and are affected both by national and global economic conditions.

To explore this framework further, the ethos and purpose of the venue will now be examined. From interviews with venue staff, this purpose is twofold. King Tut's acts as both a 'step-up' for local and up-and-coming artists to a professional venue, and as a means for DF Concerts of sourcing new artists to move up their chain of command into larger and larger venues, thereby encouraging loyalty from artists to DF at a very early stage in their career. The company's commitment to supporting local artists also shows the developmental role of the promoter, a view that has been expressed by a number of promoters spoken to so far, in that successful promoters have long-term strategies for developing future income streams for themselves by developing both the artists and the audiences that will enable them to do this. For example, King Tut's is committed to providing gigs for over-14s and provides an average of about four a month at the venue. Whilst these gigs are difficult from the point of view of the bar due to the decrease in alcohol sales, this is balanced by the fact that the promotional company runs the venue and therefore benefits from multiple income streams, including those from the sale of food during the day in the downstairs bar, and also from DF Concerts' other promotional activities.

DF Concerts promotes over a thousand concerts a year from grassroots level at King Tut's to large outdoor shows with artists such as Coldplay, Radiohead, and The Eagles, as well as Scotland's largest festival, T in the Park. The line-up for the 2009 festival included such so-called "heritage bands" as the newly reformed Blur and Jane's Addiction, as well as artists such as Glasgowbased band, Glasvegas, who first played at King Tut's in 2006 and have quickly moved up the DF Concerts' chain of command to play larger and larger venues, despite having released only one full and one mini-album (at the time of writing); thus illustrating DF Concert's use of King Tut's as a source for new artists.

Whilst deliberately maintaining a local, grassroots image via a self-created construct of authenticity - the venue was described to me by staff as being "underground but not dirty" (Coet, 2009) - and its support for local and up-andcoming artists, King Tut's, is, however, ultimately part of the global live music industry. DF Concerts, which owns the venue, is majority owned by LN-Gaiety ${ }^{1}$ a partnership between Live Nation and Irish promoter, Denis Desmond - showing how Live Nation is, albeit covertly, becoming involved at many levels within the live music industry. Speaking to the venue staff, the general opinion is that the 
involvement of Live Nation a few years ago has not changed the venue itself, apart from a slight change to the accounting system. Audience members generally hadn't noticed any changes to the venue or the way that it is run and there is no Live Nation branding within the venue itself. However, Live Nation's involvement with a seemingly 'local' venue is just one example of the way in which the global corporation has quickly become a major part of the UK's live music industry.

\section{The effects of local and national government regulation on a local live music venue}

The following section will briefly examine local and national government regulations and the ways in which the venue must adhere to statutory control. From interviews with venue staff, the following points arose: that such regulations are important at every level of the King Tut's operation, and include those relating to health \& safety, liquor licensing, the smoking ban, noise at work, and noise curfews, the latter meaning that soundchecks at King Tut's cannot begin before $6 \mathrm{pm}$ due to the close proximity of the lawyers' offices above the venue. The venue sees that their adherence to such regulations is part of what makes them a "professional" venue, as does their attention to details such as feeding the artists and providing them with shower facilities - another means of ensuring artist loyalty to King Tut's and DF Concerts - and such details as ensuring that the toilets for the audience are well stocked with toilet paper - another means of ensuring loyalty from the audience.

Interestingly, at the time of research, King Tut's was run on a public house licence and did not have a public entertainments licence due to the restrictions on capacity that such a licence would bring as opposed to a public house licence. Licensing in Scotland changed in September 2009, however, bringing such changes as the enforced provision of more female toilets, but also a stronger focus by the government on the clampdown on underage drinking. Venue staff also told me about the relatively close relationship of DF Concerts with Glasgow City Council, who apparently hold regular meetings with local promoters in order to keep them abreast of any developments that might affect them; the venue apparently also has a good relationship with the local police due to its diligent policies regarding over-14s gigs.

\section{The management and control of audience and artist expectations and interactions}

Finally, the following section will examine how the venue operates within the expectations and requirements of its artists and audiences and within the relevant genre conventions. In order to manage both the artists and the audiences, the staff at King Tut's are divided into those who are audience-facing - the bar staff and the security - and artist-facing - the production crew and the promoter's representatives, or reps. The promoter's rep is the person running the 
event and has a predominantly backstage role - or what Goffman (1959) describes as "back region"; they will only move to a "front region" position if there is a problem, for example with the guestlist (Francis, 2009). This awareness of the dual responsibility to both artist and audience is apparent from other interviews carried out with other promoters; from "sole trader" promoters right up to large promotional companies and venues.

Venue staff at King Tut's appear to understand their audiences and can generally predict behaviour by genre - one member of staff told me that "every genre has got its different breed of fan". Most of the staff stated that certain bands and genres attract certain behaviours, which the venue management must understand in order to be able to staff the venue properly. For example, the venue has a moveable crowd barrier which is put in position and staffed by sideof-stage security crew who are booked at the discretion of the promoter, depending on whether the venue believes that there will be a very active audience or crowd surfing, or if it is an over-14s gig for which the barrier is mandatory. The presence of the barrier and the side-of-stage security also acts as an overt signal to the audience about the behaviour expected of them; for example, that stage invasions will not be tolerated (Fenton, 2009).

The participant observation highlighted further overt and covert, and aural and visual signals between the various actors in the event - namely the artist, the venue staff and the audience - which influenced the behaviour of these actors within the parameters of the venue itself and within the related genre conventions. Examples of visual signals included overt encouraging signals from artist to audience such as encouraging singing along by holding the microphone out to the audience, or the venue's use of dimming and raising the houselights to indicate to the audience that the gig is about to start or has finished. Examples of aural signals included the overt discouraging signals from one audience member to another, such as shushing chatterers, or the covert use of monitor microphones which cannot be heard by the audience from the venue's sound engineer to the artist on stage.

Drawing on work by Forsyth and Cloonan in 2008 on the strategic use of music in Glasgow pubs to mould customers' behaviour, the use of music by the venue as a means of signalling to audiences about their behaviour is of particular interest. At King Tut's, this could be seen in the following ways: the venue uses an increase in volume in the downstairs bar to indicate that the doors to the venue are open and to get people in the mood to go upstairs. Background music in the upstairs venue is used as a signifier that gigs are about to start or have finished and is usually chosen to be appropriate for the headline act. One sound engineer spoke of an "industry trick", which is to use inappropriate exit music to move audiences more quickly out of the venue; for example, the use of Bruce Springsteen's slow and melancholy "Streets of Philadelphia" following a techno gig - what the sound engineer later described to me as "fuck off music" (Hepburn, 2009).

The encore ritual between artist and audience is another point of interest worth highlighting, as this was one element of the event that changed every 
night. At King Tut's, the encore has to be pre-planned between the artist and the venue in order that elements such as background music and house lights do not come back on before the encore begins. A normal encore ritual would be when the artist finishes the main set - a false ending - leaves the stage, the audience clap, cheer and whistle, and may stamp rhythmically or chant "More!" or "One more tune!", before the artist reappears for the final song and the real end of the set. The encore ritual becomes more interesting when it is disturbed, however. When a situation occurs to disrupt the "normal" encore ritual - such as one example where an amp blew and forced the band off stage before the intended encore - the encore ritual may move to the real end of the set, which tends to cause palpable confusion within the audience as the ritual of calling the artist back does not work. Once at King Tut's, the encore ritual was actively deconstructed in a humorous way by the artist to show what an odd thing it is and the audience responded in an equally humorous way to the way the artist was acting - he mimed leaving the stage, they shouted "Stamp stamp stamp!" rather than actually stamping their feet.

\section{Conclusions}

To conclude, King Tut's as a venue must necessarily operate within the local, national and global matrices of the live music industry, statutory policy and audience behaviour and expectations. As the live music industry becomes increasingly mechanized and regulated, small local venues must necessarily compete and comply in order to survive. King Tut's is fairly unusual in that it is a small venue owned by a large national promoter, with overall revenue for the parent company also coming from sources such as a major Scottish festival as well as a massive US-based company, Live Nation. However, the issues it faces and the ways in which it must understand and control audience expectations and behaviour are relevant to many promoters and venues across the UK. It is hoped, therefore, that this article has further illustrated what a rich area the study of live music can offer in understanding social behaviour and interaction, the implications for local and national policy in regard to live music, and the interaction of the local and the global for which live music is currently at the forefront.

\section{Notes}

1. According to Latham and Clayman (2009), LN-Gaiety holds a $67 \%$ share of DF Concerts and Simon Moran of promotional company SJM Concerts holds the remaining $33 \%$. However, according to a Competition Commission report into the Ticketmaster/Live Nation merger, LNGaiety owns $78 \%$ of DF Concerts (2009, p. 13). 


\section{References}

Coet, Guillaume. 2009. Interview with Emma Webster, 17 June.

Cloonan, Martin. 2009. "Researching Live Music: Some initial thoughts on policy implications", Policy and the Popular Conference, University of Leeds, Leeds, UK, June.

Competition Commission. 2009. Ticketmaster and Live Nation: A report on the anticipated merger between Ticketmaster Entertainment, Inc and Live Nation, Inc. Competition Commission, London. <http://www.competition-

commission.org.uk/rep pub/reports/2009/fulltext/552.pdf> [Accessed 29 April 2010]

Fenton, Robert. 2009. Interview with Emma Webster, 21 May.

Finnegan, Ruth H. 1989. The Hidden Musicians: music-making in an English town, Wesleyan University Press, Middletown, Conn.

Forsyth, A. \& Cloonan, M. 2008. "Alco-pop? The Use of Popular Music in Glasgow Pubs", Popular Music and Society, Vol. 31, No. 1, pp. $57-78$.

Francis, Sam. 2009. Interview with Emma Webster, 9 June.

Frith, Simon. 2007. "Live Music Matters", Scottish Music Review, Vol. 1, No. 1, pp. $1-17$.

Goffman, Erving. 1959. The presentation of self in everyday life, Penguin, London.

Hepburn, Paul. 2009. Interview with Emma Webster, 20 May.

King Tut's Wah Wah Hut. 2009. History, <http://www.kingtuts.co.uk/history.html> [Accessed 29 April 2010]

Latham, P. \& Clayman, B. 2009. Interview with Matt Brennan, 3 June.

Webb, Pete. 2007. Exploring the networked worlds of popular music: milieux cultures, Routledge, London. 